\title{
Author Correction: Timing and localization of human dystrophin isoform expression provide insights into the cognitive phenotype of Duchenne muscular dystrophy
}

\section{Nathalie Doorenweerd ${ }^{1,2,6,9}$, Ahmed Mahfouz $\mathbb{D}^{3,4}$, Maaike van Putten ${ }^{5}$, Rajaram} Kaliyaperumal $^{5}$, Peter A. C. t' Hoen ${ }^{5}$, Jos G. M. Hendriksen ${ }^{7,8}$, Annemieke M. Aartsma-Rus ${ }^{5}$, Jan J. G. M. Verschuuren $\mathbb{D}^{2}$, Erik H. Niks ${ }^{2}$, Marcel J. T. Reinders $\mathbb{D}^{4}$, Hermien E. Kan ${ }^{1,6}$ \& Boudewijn P. F. Lelieveldt $\mathbb{D}^{3,4}$

Correction to: Scientific Reports https://doi.org/10.1038/s41598-017-12981-5, published online 03 October 2017

In this Article, some of the wording in the Results section is ambiguous and should be corrected as follows:

"In contrast to previous reports ${ }^{18,29}$, the Purkinje isoform Dp427p was virtually absent in the brain throughout development, with expression levels even lower than muscle dystrophin Dp427m."

should read:

"In contrast to previous reports on mouse brain ${ }^{18,29}$, the Purkinje isoform Dp427p was virtually absent in human brain throughout development, with expression levels even lower than muscle dystrophin Dp427m.”

In addition

"Yet in line with previous studies ${ }^{30,31}, \mathrm{Dp} 427 \mathrm{p}$ was expressed in the mouse cerebellum and not in the mouse cerebral cortex."

should read:

"Yet in line with previous studies ${ }^{29,30,31}, \mathrm{Dp} 427 \mathrm{p}$ was expressed in the mouse cerebellum and not in the mouse cerebral cortex." 
(i) Open Access This article is licensed under a Creative Commons Attribution 4.0 International License, which permits use, sharing, adaptation, distribution and reproduction in any medium or format, as long as you give appropriate credit to the original author(s) and the source, provide a link to the Creative Commons license, and indicate if changes were made. The images or other third party material in this article are included in the article's Creative Commons license, unless indicated otherwise in a credit line to the material. If material is not included in the article's Creative Commons license and your intended use is not permitted by statutory regulation or exceeds the permitted use, you will need to obtain permission directly from the copyright holder. To view a copy of this license, visit http://creativecommons.org/licenses/by/4.0/.

(C) The Author(s) 2018 